ROCZNIK ADMINISTRACJI PUBLICZNEJ 2019 (5)

KOMUNIKATY / STUDY REPORTS

DOI 10.4467/24497800RAP.19.016.11481

http://www.ejournals.eu/RAP/

ISSN 2449-7800 (online), ISSN 2449-7797 (print), p. 264-268

Mykola HarBunov ${ }^{1}$

\title{
Finding Solutions to Endemic Corruption in Post-Soviet Countries
}

\section{Preliminary issues}

With the collapse of the Soviet Union in 1992, various countries formerly under Soviet domination were tasked with reimagining their governing structures. For some, however, the lack of historical association with Western European values brought by the Enlightenment and the Age of Reason led to endemic corruption characterised by bribery, embezzlement, and, in some cases, resorting to murder. There have been, however, cases where governments and societies have successfully reduced the amount of corruption, especially in the area of politics.

Corruption inhibits the growth of a country in political, social and economic terms because it:

1) undermines government revenue, thus limiting the government's ability to invest in productivity-enhancing areas,

2) distorts the decision-making related with public investment projects by diverting revenue from worthwhile projects,

3) follows the rule that the higher the level of corruption in a country, the larger the share of its economic activity consumed by corrupt practices, and

4) discourages private-sector development and innovation and encourages inefficiency. ${ }^{2}$

\section{Approaches to tackling the government's criminal activities}

Many countries have tried various approaches to rooting out political and societal corruption. However, according to the Corruption Perceptions Index (CPI), more than two-thirds of countries score below 50 (100 - good,

1 Mykola Harbunov, a first-year student of Software Engineering, O. S. Popov Odessa National Academy of Telecommunications.

2 Василий Темный, Николай Подкопаев, Борьба с коррупцией на Украине превратилась в высокодоходный бизнес, Украина.py (accessed 3.10.2018). Как победить коррупцию: «секреты» стран мира, Finance.ua (accessed 10.3.2017). 
0 - bad) on the $2017 \mathrm{CPI}^{3}$ with an average score of just 43 . This shows continued failure of most countries to significantly control corruption, which contributes to a crisis in democracy around the world. While there are exceptions, the data show that despite some progress, most countries are failing to make serious inroads against corruption.

In order to come up with solutions against corruption in post-Soviet countries, it is important to look at how various countries have approached tackling corruption and note similarities with other countries who have done the same.

\subsection{Countries}

The countries included have their 2017 CPI rating and world rank listed in [ ] after the name of the country.

$$
\text { 2.1.1. China }\left[41-77^{\text {th }}\right]
$$

According to Transparency Organisation, freedom of expression is under attack across much of the region and civic space is also shrinking severely. Civil society organisations in countries like Cambodia, Papua New Guinea and China are permanently under threat from authorities who wish to exert more control over their populace ${ }^{4}$.

That said, China has approached political and social corruption with severe measures 5 . These include: lifting immunity of officials from prosecution for wrongdoing, maintaining checks on politicians' salaries vis-à-vis their assets and bank accounts, raising salaries of public officials to deter petty bribery, independent mass media (that, however, only exposes infractions of minor party members), long prison terms and the death penalty for severe malfeasance and corruption, and changing people's mentality to report and not to tolerate corruption.

\subsubsection{Singapore $\left[84-6^{\text {th }}\right]$}

Singapore, like China, approaches political and social corruption with severe measures ${ }^{6}$. The reader is referred to its treatment of those who drop litter. Also, Singapore, unlike China, has a vibrant and truly independent media culture that is active in exposing corruption, Singaporean measures to fight corruption include: lifting of immunity of officials from prosecution for wrongdoing, maintaining checks on politicians' salaries vis-à-vis their

3 OVERVIEW, Transparency Organisation, https://www.transparency.org/research/cpi/overview.

4 Ibidem.

5 Борьба с коррупцией - зарубежный опыт: Китай и Гонконг, АРГУМЕНТ (accessed 17.12.2017).

6 Борьба с коррупцией - зарубежный опыт: от Швеции до Сингапура, АРГУМЕНТ (accessed 16.12.2017). 
assets and bank accounts, raising salaries of public officials to deter petty bribery, active independent mass media, and long prison terms.

\subsubsection{New Zealand [ $\left.89-1^{\text {st }}\right]$}

Ranked first in the $2017 \mathrm{CPI}^{7}$, New Zealand takes a unique approach in that not even the President is immune from prosecution for wrongdoing. In addition, the Serious Fraud Office (SFO), New Zealand's anti-corruption bureau, has almost unlimited authority to investigate and bring charges against any public official suspected of wrongdoing. Furthermore, just like China and Singapore mentioned above, New Zealand takes measures that include: lifting of immunity of officials from prosecution for wrongdoing, maintaining checks on politicians' salaries vis-à-vis their assets and bank accounts, active independent mass media, and society's perception of corruption as being unacceptable.

\section{Commonalities}

Given the measures of the countries listed, as well as those who rank high in the 2017 CPI ${ }^{8}$, certain commonalities can be enumerated: lifting of immunity of officials from prosecution for wrongdoing, maintaining checks on politicians' salaries vis-à-vis their assets and bank accounts, active independent mass media, and society's perception of corruption as being unacceptable.

All of these measures can be attributed to the notion of the rule of law; that is a situation in which the laws of a country are obeyed by everyone regardless of their political, economic, or social status. Any person who violates the law is duly punished for wrongdoing.

This concept is often overlooked when approaching solutions to corruption. If the general populace believes that law does not apply to everyone [emphasis added] then the perception is that it does not apply to them. Without the rule of law, bribery, corruption and other abuses of law will inevitably arise.

\section{Conclusions}

Research into how countries such as China, Singapore, New Zealand, Sweden and others have tackled the problem of political, social and economic corruption indicates that with the government's determined action and the will of the people such malfeasance can be addressed. These commonalties, including but not limited to the rule of law, removal of political immunity,

7 OVERVIEW, Transparency Organisation.

8 Ibidem. 
change of societal norms, oversight and inevitability of punishment, serve as an outline for addressing and solving ongoing corruption that plagues many countries, especially post-Soviet ones.

\section{Bibliography}

Overview, Transparency Organisation, https://www.transparency.org/research/ cpi/overview.

Борьба с коррупцией - зарубежный опыт: Китай и Гонконг, АРГУМЕНТ (accessed 17.12.2017), http://argumentua.com/stati/borba-s-korruptsiei-zarubezhnyi-opyt-kitai-i-gonkong.

Борьба с коррупцией - зарубежный опыт: от Швеции до Сингапура, АРГУМЕНТ (accessed 16.12.2017), http://argumentua.com/stati/borba-s-korruptsiei-zarubezhnyi-opyt-ot-shvetsii-do-singapura.

Василий Темный, Николай Подкопаев, Борьба с коррупцией на Украине превратилась в высокодоходный бизнес, Украина.ру (accessed 3.10.2018), https://ukraina.ru/exclusive/20181003/1021299135.html.

Как победить коррупцию: «секреты» стран мира, Finance.ua (accessed 10.3.2017), https://news.finance.ua/ru/news/-/396810/kak-pobedit-korruptsiyu-sekrety-stran-mira.

Abstract

With the fall of the Soviet Union in 1992, various countries under Soviet domination were tasked with reimagining their governing structures. For some, however, lack of historical association with Western European values led to endemic corruption characterised by bribery, embezzlement, and, in some cases, resorting to murder. There have been, however, cases where governments and societies have successfully reduced the amount of corruption, especially in the political sphere. When research into how countries such as China, Singapore, New Zealand, Sweden and others tackled this problem was conducted, there appeared certain commonalities among them. These commonalties, including but not limited to rule of law, removal of political immunity and surety of punishment, serve as an outline for addressing and solving the ongoing corruption problems that plague many countries, especially post-Soviet ones.

Keywords: corruption, political immunity, rule of law, post-Soviet

\section{Rozwiązywanie problemu endemicznej korupcji w państwach byłego ZSRR}

Streszczenie

Wraz z upadkiem Związku Radzieckiego w 1992 r. różne kraje znajdujące się w strefie sowieckich wpływów musiały na nowo określić struktury zapewniające rządzenie. W przypadku niektórych z nich brak historycznych związków z zachodnioeuropejskimi wartościami doprowadził do endemicznej korupcji, charakteryzującej się łapówkarstwem, sprzeniewierzaniem środków finansowych, a czasem nawet zabójstwami. Istnieją mimo to przykłady sytuacji, gdy rządy i społeczeństwa z powodzeniem dopro- 
wadziły do zmniejszenia poziomu korupcji, zwłaszcza w sferze politycznej. W artykule opisano przeprowadzone badania dotyczące sposobów rozwiązywania problemów korupcji endemicznej w Chinach, Singapurze, Nowej Zelandii, Szwecji i w innych krajach. Ujawniono pewne podobieństwa między nimi, w tym praworządność, zniesienie immunitetu politycznego oraz pewność kary, które służą jako kontekst niwelowania i rozwiązywania problemu trwałej korupcji trapiącego wiele państw, zwłaszcza postsowieckich.

Słowa kluczowe: korupcja, immunitet polityczny, praworządność, postsowiecki 